\title{
Moisture Absorption and Chemical Resistance Studies on Pineapple Fiber Reinforced Vinyl Ester Composite
}

\author{
M. S. Abilash, V. Arumugaprabu*, N. Rajini, P.Sivaranjana, Marxim Rahula Bharathi B
}

\begin{abstract}
This research discusses the moisture absorption and chemical resistance studies on pineapple fiber reinforced Vinyl ester composite. A composite material was developed with pineapple fiber as reinforcement in the Vinyl ester matrix. Pineapple fiber of three different weight percentages $30 \%, 40 \%$ and $50 \%$ wt as well as fiber length of $30 \mathrm{~mm}, 40 \mathrm{~mm}$ and $50 \mathrm{~mm}$ respectively taken for the study. The moisture absorption and the chemical resistance property of the composite were investigated as per the ASTM standard. Five different chemicals were used to investigate the chemical resistance behavior of the composite. The initial and final weight loss of the composites was calculated to find the moisture resistance property. The chemical resistance property was increased with the addition of treated jute fiber. All the tested composites exhibited positive results on the chemical resistance test.
\end{abstract}

Keywords: Chemical treatment, Pineapple fiber, Hybrid composite, chemical resistant test.

\section{INTRODUCTION}

Mo ost of the researchers are focused on the replacement of the synthetic fiber polyester-reinforced composites as the natural fiber reinforced polymer composites [NFPC]. Researchers focus on these materials [NFPC] having a high specific strength, modulus property, low weight ratio and costs. Environmental concerns are also good in natural fiber composites materials when compared to the synthetic fiber polyester [8] such as low density, low cost, biodegradability, flexibility during the process, minimal health hazard and high flexural modulus [9]. This research focuses on the study of pineapple fiber with Vinyl Ester resin that belongs to fiber reinforced polymer composites.

Revised Manuscript Received on December 16, 2019.

* Correspondence Author

M. S. Abilash, School of Automotive and Mechanical Engineering. Kalasalingam Academy of Research and Education, Krishnankoil-626 126, India. Email: abilash.nivas@gmail.com

V. Arumugaprabu, School of Automotive and Mechanical Engineering. Kalasalingam Academy of Research and Education, Krishnankoil-626 126, India. Email: v.arumugaprabu@klu.ac.in

N. Rajini, School of Automotive and Mechanical Engineering. Kalasalingam Academy of Research and Education, Krishnankoil-626 126, India. Email: rajiniklu@gmail.com

P.Sivaranjana, School of Automotive and Mechanical Engineering Kalasalingam Academy of Research and Education, Krishnankoil-626 126, India. Email: p.sivaranjana@klu.ac.in

Marxim Rahula Bharathi B, Department of Mechanical Engineering, Aditya College of Engineering, Surampalem, Andra Pradesh, India. Email: bmrb.2009@gmail.com

\section{MATERIALS AND METHODS}

\section{A. Material used}

Pineapple was belongs to the Bromeliaceae family. Pineapple fiber was extracted from the pinapple leaves. This pineapple fiber was purchased from the local vendor in Chennai, India Marts Pvt Ltd. The matrix used in the composites is Vinyl ester resin was procured from St.Marys Fiber Pvt. Ltd Cochin, India. Methyl ethyl ketone peroxide (MEKP) is used as an accelerator in vinyl ester resin. The property of MEKP is a colourless oily liquid and also slightly less sensitive to shock and temperature and more stable in storage in nature. Cobalt naphthenate is a mixture of cobalt derivates of naphthenic acid. These coordination complexes are widely used as oil drying agents for autoxidative cross-linking of drying oils. It is used as a catalyst in vinyl ester. N-N dimethyl aniline is an organic chemical compound, a substituted derivate of aniline. It consists of a tertiary amine, featuring a dimethyl amino group attached to a phenyl group. This oily liquid is colorless when pure but commercial samples are often yellow. It is used as a promoter in vinyl ester resin.

\section{B. Composite fabrication and mechanical testing}

For the present research pineapple fiber hybrid composite was fabricated using compression moulding process. Nine different combination composites were fabricated on the varying proportion of pineapple fiber as reinforcement. Pineapple fiber cut into various lengths of $30 \mathrm{~mm}, 40 \mathrm{~mm}$ and $50 \mathrm{~mm}$ were used as reinforcement.

\section{Moisture and chemical resistance properties}

The moisture resistance studies have been carried out as per ASTM D570-98, and as per ASTM D 543-87 standard, chemical resistance characteristics of the composites was found. The effect of few solvents such as benzene and ammonia, the effect of few acids such as acetic acid, nitric acid and hydrochloric acid were studied on the prepared composites. 
The composites were weighted initially and subjected to immersion in chemical solutions for 24 hours at room temperature. At the end of 24 hours, the specimens were taken out, dried, pressed and weighted. Using the measured weight of samples before and after the moisture, chemical test, the percentage of weight loss/gain was determined by using the following equation.

Percentage of Weight loss

$=$ Final weight- Initial Weight/ Initial weight $\times 100$.

\section{RESULTS AND DISCUSSION}

\section{A. Moisture Absorption of Pineapple fiber reinforced polyester composites}

The moisture absorption resistance of different composite combinations of pineapple fiber composites is presented in table.1. It is observed clearly from the results that in all cases, the positive values indicate that there is a weight gain takes place which proved that the composite is high resistance. Among all the composite combination of $30 \%$ wt and 50mm, fiber length possesses a high percentage of weight gain of about $30 \%$ which resists more moisture content. In general, the natural fibers can absorb more water, using reinforcing this with Vinyl ester matrix yields more resistance. The matrix holds the fiber firmly together creates a dense area where more amount of water absorbed with ease. As evident for this statement in the case of $50 \%$ wt and $50 \mathrm{~mm}$ fiber length possess good moisture resistivity. Interestingly in all the cases, the percentage of weight gain in the range of $1 \%$ to $30 \%$ noted. Apart from this few composite combinations shows an increase and decrease trend in weight gain which is due to the random arrangement of the fibers were predominantly a significant reason.

Table-1 Moisture Absorption of pineapple fiber reinforced Vinyl ester composites subjected to 24 hours

\begin{tabular}{|l|c|c|c|}
\hline $\begin{array}{l}\text { Composite } \\
\text { Combinations }\end{array}$ & $\begin{array}{l}\text { Initial } \\
\text { weight }\end{array}$ & $\begin{array}{l}\text { Final } \\
\text { weight }\end{array}$ & $\begin{array}{l}\text { \% of weight } \\
\text { gain/loss }\end{array}$ \\
\hline $\begin{array}{l}30 \% \text { wt and 30mm } \\
\text { fiber length }\end{array}$ & 1.107 & 1.113 & 0.54 \\
\hline $\begin{array}{l}30 \% \text { wt and 40mm } \\
\text { fiber length }\end{array}$ & 0.876 & 0.895 & 2.17 \\
\hline $\begin{array}{l}30 \% \text { wt and 50mm } \\
\text { fiber length }\end{array}$ & 0.735 & 0.956 & 30.07 \\
\hline $\begin{array}{l}40 \% \text { wt and 30mm } \\
\text { fiber length }\end{array}$ & 0.809 & 0.856 & 5.81 \\
\hline $\begin{array}{l}40 \% \text { wt and 40mm } \\
\text { fiber length }\end{array}$ & 1.295 & 1.302 & 0.54 \\
\hline $\begin{array}{l}40 \% \text { wt and 50mm } \\
\text { fiber length }\end{array}$ & 1.223 & 1.235 & 0.98 \\
\hline $\begin{array}{l}50 \% \text { wt and 30mm } \\
\text { fiber length }\end{array}$ & 0.705 & 0.847 & 20.14 \\
\hline $\begin{array}{l}50 \% \text { wt and } 40 \mathrm{~mm} \\
\text { fiber length }\end{array}$ & 0.808 & 0.857 & 6.06 \\
\hline $\begin{array}{l}50 \% \text { wt and } 50 \mathrm{~mm} \\
\text { fiber length }\end{array}$ & 0.913 & 1.07 & 17.20 \\
\hline
\end{tabular}

\section{B. Chemical Resistance of Pineapple fiber reinforced Vinyl ester composites}

The chemical resistance of different composite combinations of pineapple fiber composites subjected to acids is presented in table.2, and the chemical resistance of different composite combinations of pineapple fiber composites subjected to solvents is shown in table 3 respectively.

Table-2 Chemical Resistance of pineapple fiber reinforced Vinyl ester composites subjected to acids for 24 hours

\begin{tabular}{|c|c|c|c|}
\hline \multirow[b]{2}{*}{$\begin{array}{l}\text { Composite } \\
\text { Combination }\end{array}$} & \multicolumn{3}{|l|}{ HCL } \\
\hline & $\begin{array}{l}\text { Initial } \\
\text { weight }\end{array}$ & $\begin{array}{l}\text { Final } \\
\text { weight }\end{array}$ & $\begin{array}{l}\% \text { of } \\
\text { weight } \\
\text { gain/loss }\end{array}$ \\
\hline $\begin{array}{l}30 \% \text { wt and } 30 \mathrm{~mm} \\
\text { fiber length }\end{array}$ & 0.969 & 0.974 & 0.52 \\
\hline $\begin{array}{l}30 \% \text { wt and } 40 \mathrm{~mm} \\
\text { fiber length }\end{array}$ & 0.823 & 0.849 & 3.12 \\
\hline $\begin{array}{l}30 \% \text { wt and } 50 \mathrm{~mm} \\
\text { fiber length }\end{array}$ & 0.967 & 1.514 & 56.57 \\
\hline $\begin{array}{l}40 \% \text { wt and } 30 \mathrm{~mm} \\
\text { fiber length }\end{array}$ & 0.996 & 1.063 & 6.73 \\
\hline $\begin{array}{l}40 \% \text { wt and } 40 \mathrm{~mm} \\
\text { fiber length }\end{array}$ & 1.359 & 1.374 & 1.10 \\
\hline $\begin{array}{l}40 \% \text { wt and } 50 \mathrm{~mm} \\
\text { fiber length }\end{array}$ & 1.26 & 1.277 & 1.35 \\
\hline $\begin{array}{l}50 \% \text { wt and } 30 \mathrm{~mm} \\
\text { fiber length }\end{array}$ & 0.733 & 0.855 & 16.64 \\
\hline $\begin{array}{l}50 \% \text { wt and } 40 \mathrm{~mm} \\
\text { fiber length }\end{array}$ & 0.82 & 0.895 & 9.15 \\
\hline $\begin{array}{l}50 \% \text { wt and } 50 \mathrm{~mm} \\
\text { fiber length }\end{array}$ & 0.808 & 0.95 & 17.57 \\
\hline \multirow[b]{2}{*}{$\begin{array}{l}\text { Composite } \\
\text { Combination }\end{array}$} & \multicolumn{3}{|c|}{ Nitric Acid } \\
\hline & $\begin{array}{l}\text { Initial } \\
\text { weight }\end{array}$ & $\begin{array}{l}\text { Final } \\
\text { weight }\end{array}$ & $\begin{array}{l}\% \text { of } \\
\text { weight } \\
\text { gain/loss }\end{array}$ \\
\hline $\begin{array}{l}30 \% \text { wt and } 30 \mathrm{~mm} \\
\text { fiber length }\end{array}$ & 1.177 & 1.2 & 1.95 \\
\hline $\begin{array}{l}30 \% \text { wt and } 40 \mathrm{~mm} \\
\text { fiber length }\end{array}$ & 0.739 & 0.782 & 5.82 \\
\hline $\begin{array}{l}30 \% \text { wt and } 50 \mathrm{~mm} \\
\text { fiber length }\end{array}$ & 0.897 & 1.337 & 49.05 \\
\hline $\begin{array}{l}40 \% \text { wt and } 30 \mathrm{~mm} \\
\text { fiber length }\end{array}$ & 0.947 & 1.038 & 9.61 \\
\hline $\begin{array}{l}40 \% \text { wt and } 40 \mathrm{~mm} \\
\text { fiber length }\end{array}$ & 1.369 & 1.384 & 1.09 \\
\hline $\begin{array}{l}40 \% \text { wt and } 50 \mathrm{~mm} \\
\text { fiber length }\end{array}$ & 1.28 & 1.308 & 2.18 \\
\hline $\begin{array}{l}50 \% \text { wt and } 30 \mathrm{~mm} \\
\text { fiber length }\end{array}$ & 0.734 & 0.898 & 22.34 \\
\hline $\begin{array}{l}50 \% \text { wt and } 40 \mathrm{~mm} \\
\text { fiber length }\end{array}$ & 0.988 & 1.064 & 7.69 \\
\hline $\begin{array}{l}50 \% \text { wt and } 50 \mathrm{~mm} \\
\text { fiber length }\end{array}$ & 0.738 & 0.879 & 19.11 \\
\hline \multirow[b]{2}{*}{$\begin{array}{l}\text { Composite } \\
\text { Combination }\end{array}$} & \multicolumn{3}{|c|}{ Acetic Acid } \\
\hline & $\begin{array}{l}\text { Initial } \\
\text { weight }\end{array}$ & $\begin{array}{l}\text { Final } \\
\text { weight }\end{array}$ & $\begin{array}{l}\text { \% of } \\
\text { weight } \\
\text { gain/loss }\end{array}$ \\
\hline $\begin{array}{l}30 \% \text { wt and } 30 \mathrm{~mm} \\
\text { fiber length }\end{array}$ & 1.153 & 1.155 & 0.17 \\
\hline $\begin{array}{l}30 \% \text { wt and } 40 \mathrm{~mm} \\
\text { fiber length }\end{array}$ & 0.752 & 0.718 & -4.52 \\
\hline $\begin{array}{l}30 \% \text { wt and } 50 \mathrm{~mm} \\
\text { fiber length }\end{array}$ & 0.678 & 0.946 & 39.53 \\
\hline $\begin{array}{l}40 \% \text { wt and } 30 \mathrm{~mm} \\
\text { fiber length }\end{array}$ & 0.902 & 0.933 & 3.44 \\
\hline $\begin{array}{l}40 \% \text { wt and } 40 \mathrm{~mm} \\
\text { fiber length }\end{array}$ & 1.376 & 1.384 & 0.58 \\
\hline
\end{tabular}




\begin{tabular}{|l|l|l|l|}
\hline $\begin{array}{l}40 \% \text { wt and 50mm } \\
\text { fiber length }\end{array}$ & 1.144 & 1.561 & 36.45 \\
\hline $\begin{array}{l}50 \% \text { wt and 30mm } \\
\text { fiber length }\end{array}$ & 0.786 & 0.917 & 16.67 \\
\hline $\begin{array}{l}50 \% \text { wt and 40mm } \\
\text { fiber length }\end{array}$ & 0.889 & 0.949 & 6.75 \\
\hline $\begin{array}{l}50 \% \text { wt and 50mm } \\
\text { fiber length }\end{array}$ & 0.801 & 0.903 & 12.73 \\
\hline
\end{tabular}

Table-3 Chemical Resistance of pineapple fiber reinforced Vinyl ester composites subjected to solvents for 24 hours

\begin{tabular}{|c|c|c|c|}
\hline \multirow[b]{2}{*}{$\begin{array}{l}\text { Composite } \\
\text { Combination }\end{array}$} & \multicolumn{3}{|c|}{ Benzene } \\
\hline & $\begin{array}{l}\text { Initial } \\
\text { weight }\end{array}$ & $\begin{array}{l}\text { Final } \\
\text { weight }\end{array}$ & $\begin{array}{l}\text { \% of weight } \\
\text { gain/loss }\end{array}$ \\
\hline $\begin{array}{l}30 \% \text { wt and } 30 \mathrm{~mm} \\
\text { fiber length }\end{array}$ & 1.024 & 1.032 & 0.78 \\
\hline $\begin{array}{l}30 \% \text { wt and } 40 \mathrm{~mm} \\
\text { fiber length }\end{array}$ & 0.916 & 0.939 & 2.51 \\
\hline $\begin{array}{l}30 \% \text { wt and } 50 \mathrm{~mm} \\
\text { fiber length }\end{array}$ & 0.719 & 0.826 & 14.88 \\
\hline $\begin{array}{l}40 \% \text { wt and } 30 \mathrm{~mm} \\
\text { fiber length }\end{array}$ & 0.93 & 1.008 & 8.38 \\
\hline $\begin{array}{l}40 \% \text { wt and } 40 \mathrm{~mm} \\
\text { fiber length }\end{array}$ & 1.387 & 1.39 & 0.22 \\
\hline $\begin{array}{l}40 \% \text { wt and } 50 \mathrm{~mm} \\
\text { fiber length }\end{array}$ & 1.287 & 1.098 & -14.69 \\
\hline $\begin{array}{l}50 \% \text { wt and } 30 \mathrm{~mm} \\
\text { fiber length }\end{array}$ & 0.748 & 0.808 & 8.021 \\
\hline $\begin{array}{l}50 \% \text { wt and } 40 \mathrm{~mm} \\
\text { fiber length }\end{array}$ & 0.9481 & 1 & 5.47 \\
\hline $\begin{array}{l}50 \% \text { wt and } 50 \mathrm{~mm} \\
\text { fiber length }\end{array}$ & 0.871 & 1.011 & 16.07 \\
\hline \multirow[b]{2}{*}{$\begin{array}{l}\text { Composite } \\
\text { Combination }\end{array}$} & \multicolumn{3}{|c|}{ Ammonia } \\
\hline & $\begin{array}{l}\text { Initial } \\
\text { weight }\end{array}$ & $\begin{array}{l}\text { Final } \\
\text { weight }\end{array}$ & $\begin{array}{l}\% \text { of weight } \\
\text { gain/loss }\end{array}$ \\
\hline $\begin{array}{l}30 \% \text { wt and } 30 \mathrm{~mm} \\
\text { fiber length }\end{array}$ & 1.213 & 1.218 & 0.41 \\
\hline $\begin{array}{l}30 \% \text { wt and } 40 \mathrm{~mm} \\
\text { fiber length }\end{array}$ & 0.718 & 0.804 & 11.97 \\
\hline $\begin{array}{l}30 \% \text { wt and } 50 \mathrm{~mm} \\
\text { fiber length }\end{array}$ & 1.018 & 1.51 & 48.33 \\
\hline $\begin{array}{l}40 \% \text { wt and } 30 \mathrm{~mm} \\
\text { fiber length }\end{array}$ & 0.881 & 0.923 & 4.77 \\
\hline $\begin{array}{l}40 \% \text { wt and } 40 \mathrm{~mm} \\
\text { fiber length }\end{array}$ & 1.25 & 1.5261 & 22.08 \\
\hline $\begin{array}{l}40 \% \text { wt and } 50 \mathrm{~mm} \\
\text { fiber length }\end{array}$ & 1.301 & 1.322 & 1.61 \\
\hline $\begin{array}{l}50 \% \text { wt and } 30 \mathrm{~mm} \\
\text { fiber length }\end{array}$ & 0.784 & 0.884 & 12.76 \\
\hline $\begin{array}{l}50 \% \text { wt and } 40 \mathrm{~mm} \\
\text { fiber length }\end{array}$ & 0.918 & 0.945 & 2.94 \\
\hline $\begin{array}{l}50 \% \text { wt and } 50 \mathrm{~mm} \\
\text { fiber length }\end{array}$ & 0.91 & 1.08 & 18.68 \\
\hline
\end{tabular}

The stability of the composites to the chemical attack can be found through the chemical resistance test. This ensures the acceptability of these composites in the chemical orientated applications. The results of the chemical-resistant test are shown in the table. The numeric value in the table is the weight loss and weight gain of the composite for 24 hours of chemical immersion. It is noted that the maximum number of composites has gained weight after the chemical resistance test and any only few composites showed negative signs. The negative sign indicates the inability of composite against the chemical etching. When the composite surface exposed to the chemical, the chemical molecules starts attacking the surface.
When the composite surface is damaged, and fiber reinforcement is exposed. At this condition, the chemical quickly degrades the fiber and contaminate the material. This leads to weight loss in the material. This occurred mainly because of the uneven bonding between the fiber and matrix. But the majority of the composites showed positive results against the chemical resistant test. This ensures that these composites were stable and resistant to the chemical attack. It is noted that more weight gain was noted on the nitric acid solution at $30 \%$ wt and $50 \mathrm{~mm}$ fiber length. The increase in weight is mainly because of the hydrophilicity nature of the fiber. Overall, all the developed composites showed better resistance to the chemical attack. The improved bonding at high weight percentage reduced the possibility of a chemical attack on the fiber reinforcement.

\section{CONCLUSION}

In the present work, Pineapple fiber reinforced Vinyl ester composite is successfully fabricated, and the chemical resistance test was done. From the experimental result outcome, the following conclusions were drawn. The composites showed excellent resistance to the chemical treated fiber reinforcement. This chemical resistance test indicates that the untreated fiber composites are strongly resistant to almost all substances, and maximum weight gain was noted on HCL acid. The above observations suggest that these composites can be used in chemical erosion resistance applications.

\section{REFERENCES}

1. Dhand, Vivek, Garima Mittal, Kyong Yop Rhee, Soo-Jin Park, and David Hui. "A short review on basalt fiber reinforced polymer composites." Composites Part B: Engineering 73 (2015): 166-180.

2. Mohammed, Layth, MOHAMED NM Ansari, Grace Pua, Mohammad Jawaid, and M. Saiful Islam. "A review on natural fiber reinforced polymer composite and its applications." International Journal of Polymer Science 2015 (2015).

3. Mohammed, Layth, MOHAMED NM Ansari, Grace Pua, Mohammad Jawaid, and M. Saiful Islam. "A review on natural fiber reinforced polymer composite and its applications." International Journal of Polymer Science 2015 (2015).

4. Saheb, D. Nabi, and Jyoti P. Jog. "Natural fiber polymer composites: a review." Advances in Polymer Technology: Journal of the Polymer Processing Institute 18, no. 4 (1999): 351-363.

5. Tsenoglou, Christos J., Sylvia Pavlidou, and Constantine D. Papaspyrides. "Evaluation of interfacial relaxation due to water absorption in fiber-polymer composites." Composites science and technology 66, no. 15 (2006): 2855-2864.

6. Jawaid, M., HPS Abdul Khalil, A. Abu Bakar, and P. Noorunnisa Khanam. "Chemical resistance, void content and tensile properties of oil palm/jute fiber reinforced polymer hybrid composites." Materials \& Design 32, no. 2 (2011): 1014-1019.

7. Uthayakumar, M., V. Manikandan, N. Rajini, and P. Jeyaraj "Influence of redmud on the mechanical, damping and chemical resistance properties of banana/polyester hybrid composites." Materials \& Design 64 (2014): 270-279.

8. R. Deepak Joel Johnson, V. Arumugaprabu, Manapurapu Prem Kumar, and Kothapalli Dheeraj "Solid particle erosion on the biochar filled hybrid vinyl ester composite".

9. Oluyemi Ojo DARAMOLA1,*, Adeolu Adesoji ADEDIRAN2, Benjamin Omotayo ADEWUYI1, and Olamigoke ADEWOLE1 "Mechanical properties and water absorption behaviour of treated pineapple leaf fiber reinforced polyester matrix composites". 


\section{AUTHORS PROFILE}

M.S. Abilash has received master degree in CAD/CAM from Kumaraguru College of Engineering \& Technology, Coimbatore, India. He is currently as the Research Scholar at Kalasalingam Academy of Research and Education in the Department of Mechanical Engineering. He has 7 years of Academic Experience

V. Arumugaprabu working as Associate Professor in the Department of Mechanical Engineering, School of Automotive and Mechanical Engineering, Kalasalingam Academy of Research and education, Krishnankoil, Tamil $\mathrm{Nadu}$, India. He graduated B.E in Mechanical Engineering at AKCE in the year 2005, Graduated M.E in CAD/CAM at Mepco Schlenk Engg., college, Graduated Ph.D in Composite Materials in the year 2014 at Kalasalingam University, India. Also worked as Post Doc Research Associate in Precision Machining Lab, School of Mechanical Engineering, Yeungnam University, South Korea in the year 2017. He has very vast research experience in the field of composite materials with nearly 50 publications in various reputed SCI Journals and has nearly 40 publications in various International and National conferences.

N. Rajini working as Professor in the Department of Mechanical Engineering, School of Automotive and Mechanical Engineering, Kalasalingam Academy of Research and education, Krishnankoil, Tamil Nadu, India.. He has very vast research experience in the field of composite materials with nearly 100 publications in various reputed SCI Journals and very vast teaching experience of 15 years.

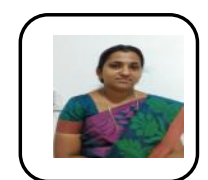

P. Sivaranjana working as assistant professor in the Department of Chemistry, School of Advanced Sciences, Kalasalingam Academy of Research and education. Her area of research is in biocomposites and she has very vast teaching experience of 13 years.

MarximRahulaBharathi B has received his $\mathrm{Ph} . \mathrm{D}$.

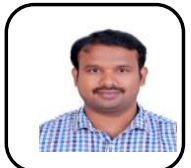
from Indian Institute of Technology, Kharagpur, India in Mechanical Engineering and his M.E. from AC College of Engineering and Technology, Karaikudi, Tamilnadu, India. He is currently working as Assistant Professor in the Department of Mechanical Engineering at Aditya College of Engineering, Surampalem, India. He has 6 years of research experience, and 2 years of Academic experience. 